\title{
Some Biochemical Changes of Rat Hippocampal Slices under the Long-term Creatine Intraperitoneal Supplementation
}

\author{
Burjanadze George*, Shengelia Mariam, Dachanidze Natalia, Koshoridze Marine, Menabde Ketevan, \\ Tsagareli Sulkhan, Koshoridze Nana
}

Department of Biology, Faculty of Exact and Natural Sciences, I. Javakhishvili Tbilisi State University, Tbilisi, 0179, Georgia

Copyright $\bigcirc 2016$ by authors, all rights reserved. Authors agree that this article remains permanently open access under the terms of the Creative Commons Attribution License 4.0 International License

\begin{abstract}
For the last few decades, aggression has been linked to various modifications in cellular metabolic pathways. It has also been shown that patients undergoing extended creatine (Cr) treatment display increased aggressiveness. However, molecular mechanisms underlying a correlation between the two phenomena have not been sufficiently identified. To gain a deeper understanding of the changes resulting from supplementation of $\mathrm{Cr}$ into non-aggressive animals, we compared some behavioral and biochemical characteristics of Cr-treated and originally non-aggressive individuals with those of naturally non-aggressive and naturally aggressive groups. In this paper we show that extended supplementation of creatine into non-aggressive animals modifies the number of exploratory characteristics and fear-related reactions. In addition, it also changes several biochemical properties in the hippocampus among rats, by significantly reducing the content of $\mathrm{Ca}^{2+}$ ions. This could be the result of Cr's direct influence on the NMDA-receptor and its functional inhibition. In conclusion, behavioral and biochemical parameters of non-aggressive individuals display changes under extended supplementation of creatine, which could provide a significant insight into formation of aggression-related behaviors and processes.
\end{abstract}

Keywords Aggressive Behavior, Creatine, $\mathrm{Ca}^{2+}$-ATPase, $\mathrm{Na}^{+} / \mathrm{K}^{+}$-ATPase, $\mathrm{Mg}^{2+}$-ATPase, Calcium

\section{Introduction}

Creatine (Cr) ( $\alpha$-N-methylguanidino acetic acid) is an organic compound, which, with phosphocreatine (PCr), plays an important role in energy metabolism in the cell. The reaction is catalyzed by the enzyme Creatine Kinase (CK), which can be found in almost all types of cells, with the most active isoforms in tissues with high-energy demand, particularly in muscle and brain $[1,2]$.

Apart from the key role of $\mathrm{Cr}$ in energy metabolism, it also presumably performs a number of other functions too, such as transmission of nerve impulses in synapses, maintaining membrane potential and ion gradient, cellular homeostasis, axonal and dendritic transport and participation in other important processes in the central nervous system [3, 4]. There is data showing that $\mathrm{Cr}$ can also serve as a neuromodulator and activate or inhibit certain post-synaptic receptors [5].

At the same time, the phenotypic diversity of neurological diseases observed under $\mathrm{Cr}$ deficiency points to the importance of the compound in terms of psychomotor development and realization of cognitive functions [6]. It has been found that quantitative deficit of $\mathrm{Cr}$ affects functionality of the central nervous system and has external effects on neurodegenerative deseases $[7,8,9]$. On the other hand, increase in the Cr quantity has a neurptotective effect [10]. $\mathrm{Cr}$ is characterized by similar features in a number of psychiatric diseases, such as schizophrenia, psychological stress, etc $[11,12,13,14]$.

Activity of the enzymes found in the central nervous system (L-arginie: glicine amidinotransferase (AGAT) and guanidinoacetate methyltransferase (GAMT) shows that the brain can endogenously synthesize $\mathrm{Cr}$ [15]. However, the Cr-specific transporter SLC6A8, which is present in endothelial cells of micro-capillaries can import $\mathrm{Cr}$ through the blood-brain barrier (BBB) [16]. Activity of AGAT and GAMT depends on a variety of conditions in the central nervous system, including oxidative stress. Oxidative stress is known to have a negative influence on the performance of mitochondria and, hence, on the energy homeostasis [15]. Use of exogenous $\mathrm{Cr}$ improves cognitive functionality of the brain, making it potentially possible to apply the compound as a pharmacological agent to treat a number of mental disorders [17]. However, it has also been claimed that 
supplementing Cr over an extended period of time raises the level of aggressiveness in an individual and gives rise to aggressive behavior. On the other hand, there is no experimental data to confirm this point of view, which is mainly based on positive changes of behavioral parameters among depressed animals [14, 18].

The aim of our experiment was to study the role of intraperitoneally (i.p.) supplemented $\mathrm{Cr}$ in activation of certain processes that are known to be characteristic of aggression in general and the influence it has on biochemical mechanisms, which are closely linked to development of several biochemical processes.

\section{Materials and Methods}

\subsection{Study Design}

Experiments were conducted on 200-250 gr male Sprague-Dawley rats. As per the mouse-killing test (MKT) a single adult mouse was placed in the home cage with a single rat for $5 \mathrm{~min}$. The time to each lethal attack was recorded. Dead mice and survivors were removed from the cage at the end of the behavioral test session. The killer behavior of the rat was taken as a sign of aggression [19]. According to the results of the test, the animals were divided into three main groups: G1 - non-aggressive, G2 - non-aggressive Cr-treated (30 days), and G3 - aggressive individuals, ten animals in each group. The experiment was repeated for three individual series.

The open-field test followed a modified Brittney and co-authors' method [20] and assessed the changes in fearand anxiety-related reactions, as well as in the exploratory activity of the three groups.

The test chamber represented a black $50 \mathrm{~cm} \times 50 \mathrm{~cm} \times 50$ $\mathrm{cm}$ Plexiglas cube, with a light bulb $(60 \mathrm{~W})$ placed at $40 \mathrm{~cm}$ from the floor. At the beginning of the test, each animal was introduced into the same left back corner of the arena and allowed to explore the arena freely for $5 \mathrm{~min}$. The floor of the field was divided into 4 equal squares and the central zone. The number of entries into the center, ambulation (line-crossing), rearing, grooming, defecation and freezing was counted and recorded.

The open-field camera contained an additional dark box that was separated from the light compartment by a wall with an opening $(13 \times 5 \mathrm{~cm})$ at the floor level. The number of entries into the dark box was also counted and the time spent there was measured.

The experiments were conducted in full accordance with the legal and statutory acts applicable in Georgia and the international agreements ratified by the country, such as the Law of Georgia on Health Care and European Convention for the Protection of Vertebrate Animals Used for Experimental and Other Scientific Purposes.

\subsection{Creatine Supplementation}

$\mathrm{Cr}$ was purchased from Sigma-Aldrich (St. Louis, MO, USA), and diluted in 5\% dimethyl sulfoxide (DMSO). 140 $\mathrm{mg} / \mathrm{kg} /$ day was i.p. injected into the non-aggressive animals during 30 days. The rest of the experimental animals were supplemented with 5\% dimethyl sulfoxide, depending on the animal weight ( $1 \mathrm{ml} / 100 \mathrm{gr}$ ). The $\mathrm{Cr}$ dose to be injected was chosen based on the data taken from the research by various authors $[21,22]$.

\subsection{Preparation of Plasma Membrane from Hippocampal Slices}

Slices of the hippocampus were homogenized in a sucrose solution containing (in $\mathrm{mM}$ ) 250 Sucrose, 10 Tris- $\mathrm{HCl}$ and 1 EDTA (pH 7.7). The homogenate was centrifuged at $1000 \times$ $\mathrm{g}$ for $10 \mathrm{~min}$ at $4^{\circ} \mathrm{C}$ to remove excess debris. The supernatant was removed and centrifuged at $7700 \times \mathrm{g}$ for $20 \mathrm{~min}$ at $4^{\circ} \mathrm{C}$, followed by centrifugation of the supernatant at $7700 \times \mathrm{g}$ for $5 \mathrm{~min}$ at $4^{\circ} \mathrm{C}$. The supernatant was then centrifuged at 55,000 $\times \mathrm{g}$ for $30 \mathrm{~min}$ at $4^{\circ} \mathrm{C}$. The precipitate was re-suspended into Tris- $\mathrm{HCl}$ buffer ( $\mathrm{pH} 7.7$ ) and frozen at $-20^{\circ} \mathrm{C}$ before the use [23].

\subsection{Measurement of Total $\mathrm{No}_{\mathrm{x}}$ Level}

The level of $\mathrm{NO}_{\mathrm{x}}$ in hippocampal samples was determined by a modified method of Miranda et al. [24].

As the first step, sample deproteinization was achieved by adding equal volumes $0.3 \mathrm{M} \mathrm{NaOH}$ to $100 \mu \mathrm{l}$ of tissue homogenate. It was mixed well and incubated for $5 \mathrm{~min}$ at room temperature (RT). Then $100 \mu \mathrm{l}$ of $5 \% \mathrm{ZnSO}_{4}$ was added, mixed well and incubated for additional 5 min at RT. After the incubation the mixtures were centrifuged at 3000 $\mathrm{rpm}$ at $4^{\circ} \mathrm{C}$ for $15 \mathrm{~min}$. An aliquot of $100 \mu \mathrm{l}$ of the clear supernatant was then mixed with $200 \mu$ of Griess Reagent. Griess Reagent was prepared just prior to the assay and contained $0.25 \% \mathrm{VCl}_{3}, 0.1 \%$ sulfanilamide and $0.05 \%$ $\mathrm{N}$-(1-Naphthyl)-ethylene diamine (NEDD) in $0.5 \mathrm{M} \mathrm{HCl}$. Reagent blank was the same, but contained $100 \mu \mathrm{l}$ of distilled water instead of the sample. The mixture was incubated for $30 \mathrm{~min}$ at $37^{\circ} \mathrm{C}$ and absorbance was measured at $540 \mathrm{~nm}$ with a microplate reader (Multiscan GO, Thermo Fischer Scientific, Finland).

The standard curve for $\mathrm{NaNO}_{2}$ was used to calculate total NO concentration in the samples.

\subsection{Quantitative Determination of $\mathrm{Ca}^{2+}$ Concentration}

The calcium concentration was determined with a commercial colorimetric kit (Sigma-Aldrich, cat. \# MAK022, St. Louis, MO, USA). The calcium ion concentration was determined by the chromogenic complex formed between $\mathrm{Ca}^{2+}$ and O-cresolphthalein. Absorbance of the $\mathrm{Ca}^{2+}-\mathrm{O}$-cresolphtalein complex was measured at $575 \mathrm{~nm}$ and was proportional to the concentration of calcium ions present. 


\subsection{Assessment of the $\mathrm{Ca}^{2+}$-ATPase Activity}

$\mathrm{Ca}^{2+}$-ATPase activity was determined by the amount of inorganic phosphate released after the reaction. The assay medium (1 ml) contained $50 \mathrm{mM}$ Tris- $\mathrm{HCl}$ buffer ( $\mathrm{pH} 7.4)$, $0.4 \mathrm{mM} \mathrm{MgCl}{ }_{2}$ or $0.4 \mathrm{mM} \mathrm{CaCl}_{2}, 2 \mathrm{mM} \mathrm{ATP}$, and the protein fraction ( $50 \mu \mathrm{g}$ proteins). After $15 \mathrm{~min}$ of incubation at $37^{\circ} \mathrm{C}$ the reaction was stopped by adding $1.2 \mathrm{ml}$ of ice-cold $10 \%$ trichloroacetic acid. The $\mathrm{Ca}^{2+}$-ATPase activity was taken as the difference between the values of enzyme activity in the presence and absence of $\mathrm{Ca}^{2+}[18]$.

\subsection{Determination of $\mathrm{Na}^{+} / \mathrm{K}^{+}$-ATPase and $\mathrm{Mg}^{2+}$-ATPase Activity}

$\mathrm{Na}^{+} / \mathrm{K}^{+}$-ATPase activity was calculated as the difference between total ATPase activity $\left(\mathrm{Na}^{+} / \mathrm{K}^{+}, \mathrm{Mg}^{2+}\right.$-dependent) and $\mathrm{Mg}^{2+}$-dependent ATPase activity. Total ATPase activity was assayed at $37^{\circ} \mathrm{C}$ in an incubation medium consisting of $50 \mathrm{mM}$ Tris-HCl, pH 7.4,120 mM NaCl, $20 \mathrm{mM} \mathrm{KC1}, 4 \mathrm{mM}$ $\mathrm{MgCl}_{2}, 3 \mathrm{mM}$ disodium ATP and 80-100 $\mu \mathrm{g}$ protein of the plasma membrane, total $1 \mathrm{ml}$. Ouabain $(1 \mathrm{mM})$ was added to the medium to determine the activity of the $\mathrm{Mg}^{2+}$-ATPase. The values of $\mathrm{Mg}^{2+}$-ATPase (1) with $\mathrm{NaCl}, \mathrm{KCl}$ and $\mathrm{MgCl}_{2}$ and (2) with $\mathrm{MgCl}_{2}$ only were compared. The amount of inorganic phosphate (Pi) released was quantified calorimetrically, as described by Fiske and Subbarow (1925), using $\mathrm{KH}_{2} \mathrm{PO}_{4}$ as a reference standard. Specific $\mathrm{Na}^{+} / \mathrm{K}^{+}$-ATPase and $\mathrm{Mg}^{2+}$-ATPase activities were computed by subtracting the blank from the overall activity and expressed in $\mu \mathrm{mol} \mathrm{Pi} / \mathrm{mg}$ protein $/ \mathrm{min}$ [23].

\subsection{Statistical Analysis}

All statistical analyses were conducted by using SPSS software (version 23, SPSS, Chicago, IL). One-way ANOVA was used to assess group differences in all physiological and biochemical values. Tukey HSD or Games-Howell post hoc test was performed to assess the differences between groups. The values are expressed as the mean \pm SEM. $\mathrm{P}$ values less than 0.05 were considered as statistically significant.

\section{Results}

The results presented in Figure 1 indicate that the non-aggressive (G1) and the naturally aggressive or killer animals (G3) differ in certain behavioral parameters. Particularly, G3 shows a significant increase in the number of line-crossings in the big chamber of the experimental cage $(F(2,36)=15.102 ; p<0.05)$, the number of entries into the dark box $(F(2,36)=4.552 ; \mathrm{p}<0.05)$, as well as the number of rearing $(F(2,36)=16.270 ; p<0.001)$. Certain fear-related reactions showed a decline. This, in particular, concerns the number of defecations $(\mathrm{F}(2,36)=4.754 ; \mathrm{p}<0.05)$ and freezing $(\mathrm{F}(2,36)=11.827 ; \mathrm{p}<0.0001)$. The time spent in the dark box and number of grooming did not vary significantly.

In order to establish the influence of $\mathrm{Cr}$ on the behavioral parameters we further studied the latter in the non-aggressive individuals that had been daily injected $140 \mathrm{mg} / \mathrm{kg}$ of Cr for 30 days (G2). The obtained data show that similar to G3 animals, they displayed an increase in locomotor activity compared to that among the control group (G1). Just as in the case described above, the number of ambulation $(\mathrm{F}(2,36)=$ $15.102 ; \mathrm{p}<0.001)$ and frequency of rearing $(\mathrm{F}(2,36)=$ $16.270 ; \mathrm{p}<0.001)$ increased. Likewise, the frequency of fear-related behaviors, such as freezing $(\mathrm{F}(2,36)=11.827$; $\mathrm{p}<0.05)$ and defecation $(\mathrm{F}(2,36)=4.754 ; \mathrm{p}<0.05)$, was reduced. The other behavioral parameters did not vary significantly.

In order to find how behavioral parameters among non-aggressive animals relate to those of aggressive individuals under the influence of i.p. injected creatine, we further compared these two groups. The difference was not statistically significant in any parameter, except in parameter $a(F(2,36)=15.102 ; p<0.05)$.

Apart from behavioral parameters, we also studied certain biochemical markers. The experiments showed that $\mathrm{Cr}$ supplementation has a significant effect on the NO level in hippocampal samples, which was reduced in $\mathrm{G} 2$ compared to G1 individuals $(F(2,21)=6.574 ; p<0.01)$. Similar to the behavioral data, no changes were found between the NO levels in G2 and G3 individuals (Fig.2a).

Repeated measures ANOVA showed a significant change in $\mathrm{Ca}^{2+}$ levels $(\mathrm{F}(2,21)=13.319 ; \mathrm{p}<0.001)$ across the three groups. Results of a post hoc analysis (Games-Howell) to compare G1 and G3 animals was nonsignificant, while G2 members displayed a statistically significant decrease in the ion concentration in hippocampal samples compared to $\mathrm{G} 1$ $(\mathrm{p}<0.001)$ and $\mathrm{G} 3(\mathrm{p}<0.05)$.

The next step was to study changes in the activity of some transport ATPases in the hippocampal slices of experimental rats.

The data presented in Figure 3a shows that $\mathrm{Cr}$ supplementation has no impact on non-aggressive animals' hippocampal plasma membrane $\mathrm{Ca}^{2+}$-ATPase (PMCA) activity, nor were any differences found between G1 and G3. Microsomal $\mathrm{Ca}^{2+}$-ATPase (MCA) activity did not change either (Fig. 3b). Considering the importance of mitochondrial $\mathrm{Ca}^{2+}$-ATPase (MitCA) in maintaining intracellular $\mathrm{Ca}^{2+}$ levels, change in the activity of MitCA was also monitored, but the results were similar to the above and the groups did not vary considerably (Fig. 3c).

Unlike the $\mathrm{Ca}^{2+}$-ATPase, $\mathrm{Na}^{+} / \mathrm{K}^{+}$-ATPase showed a statistically significant increase under $\mathrm{Cr}$-supplementation (G2) compared to $\mathrm{G} 1$ individuals, $\mathrm{F}(2,21)=138.420$; $\mathrm{p}<0.001$, which was also true for G3 (Fig. 4a). Tukey HSD post hoc test detected a $37 \%$ increase in the $\mathrm{Na}^{+} / \mathrm{K}^{+}$-ATPase activity of $\mathrm{G} 2$ animals $(\mathrm{p}<0.001)$, the same indicator being approximately $11 \%$ for $\mathrm{G} 3$ individuals $(\mathrm{p}<0.01)$; and the increase in enzyme activity of G2 animals was equal to $27 \%$, compared to $\mathrm{G} 3(\mathrm{p}<0.001)$. 
No statistically significant changes were found in the case to aggressive or non-aggressive animals does not affect its of $\mathrm{Mg}^{2+}$-ATPase, indicating that 30-day Cr supplementation enzymatic activity (Fig. 4b).
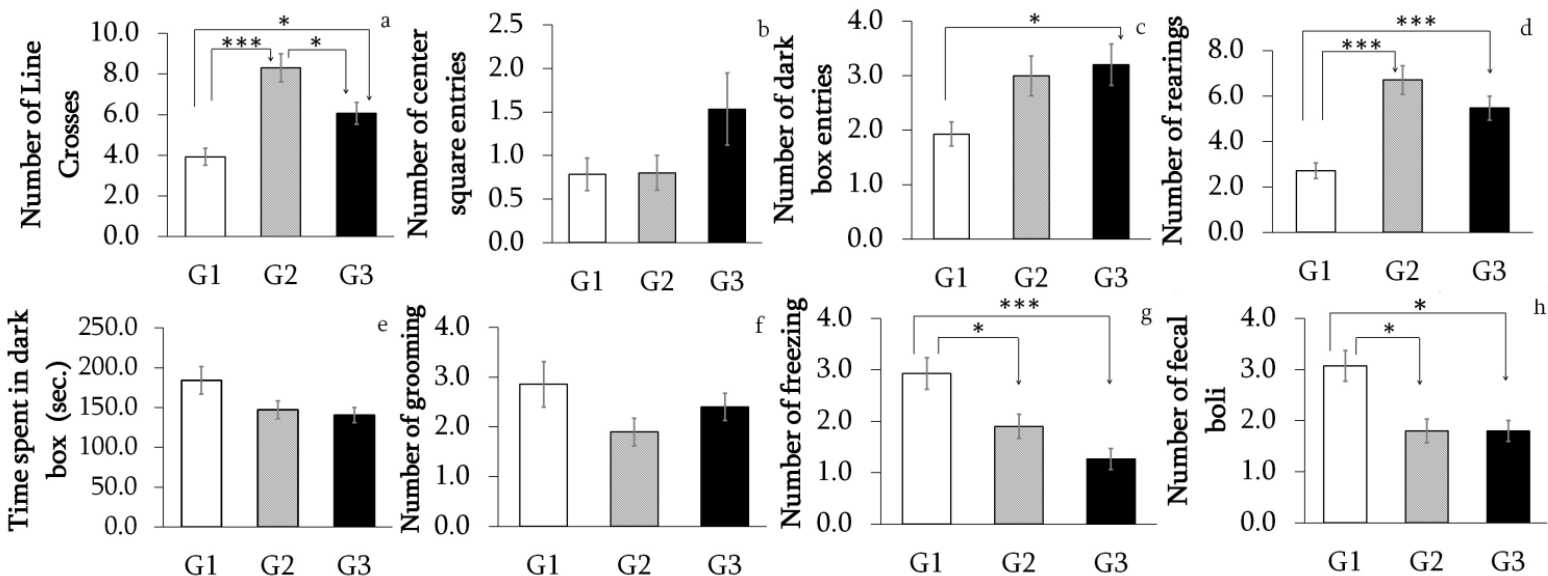

Figure 1. Behavioral characteristics of Non-aggressive (G1), Cr-treated non-aggressive (G2) and Aggressive (G3) animals in open field. a - number of line crossed; $b$ - center square entries; $c$ - entries in dark box; $d$ - rearing frequency; e - time spent in the box camera (sec.); $f$ - number of freezing; $g$ - number of grooming; $\mathrm{h}$ - defecation. Data are mean $\pm \mathrm{SEM}$ for $\mathrm{n}=10-15$ in each group. ${ }^{*} \mathrm{p}<0.05, * * * \mathrm{p}<0.001$

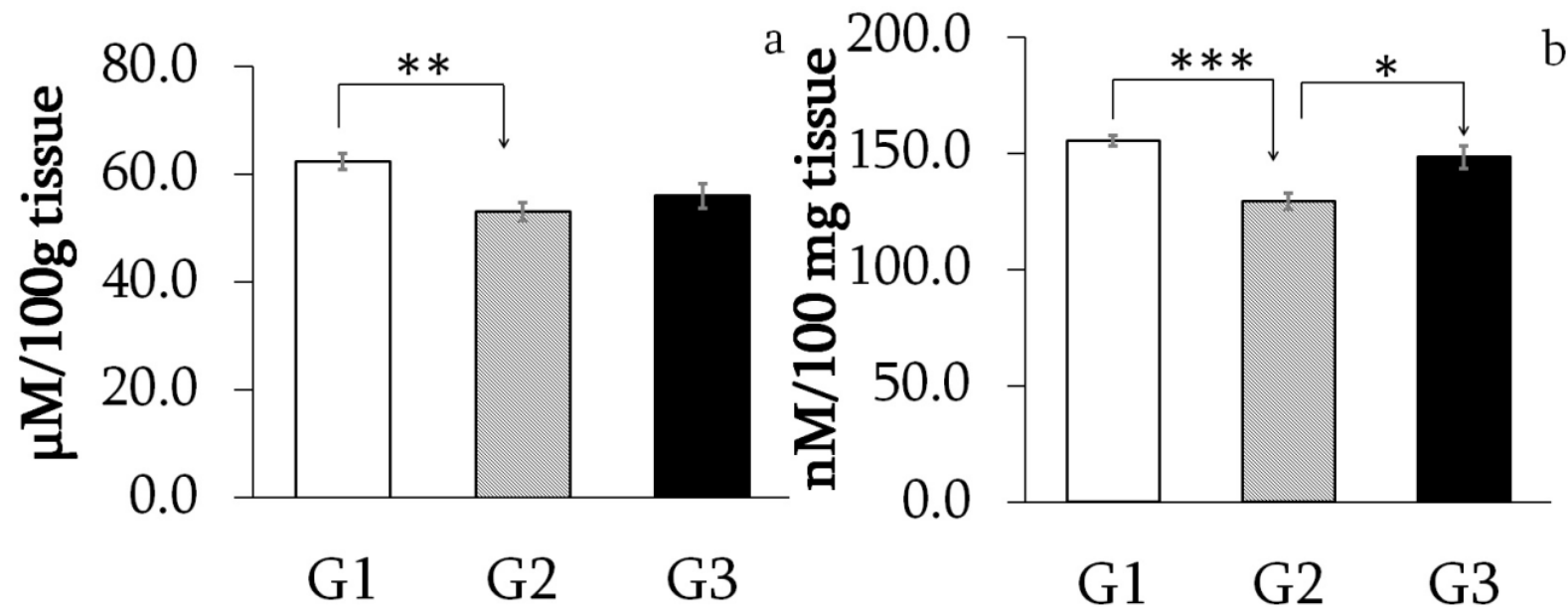

Figure 2. Alteration in $\mathrm{NO}$ (a) and $\mathrm{Ca}^{2+}$ (b) levels in Non-aggressive (G1), Cr-treated non-aggressive (G2) and Aggressive (G3) animals. Data are mean \pm SEM for $n=8$ in each group. ${ }^{*} \mathrm{p}<0.05, * * \mathrm{p}<0.01, * * * \mathrm{p}<0.001$

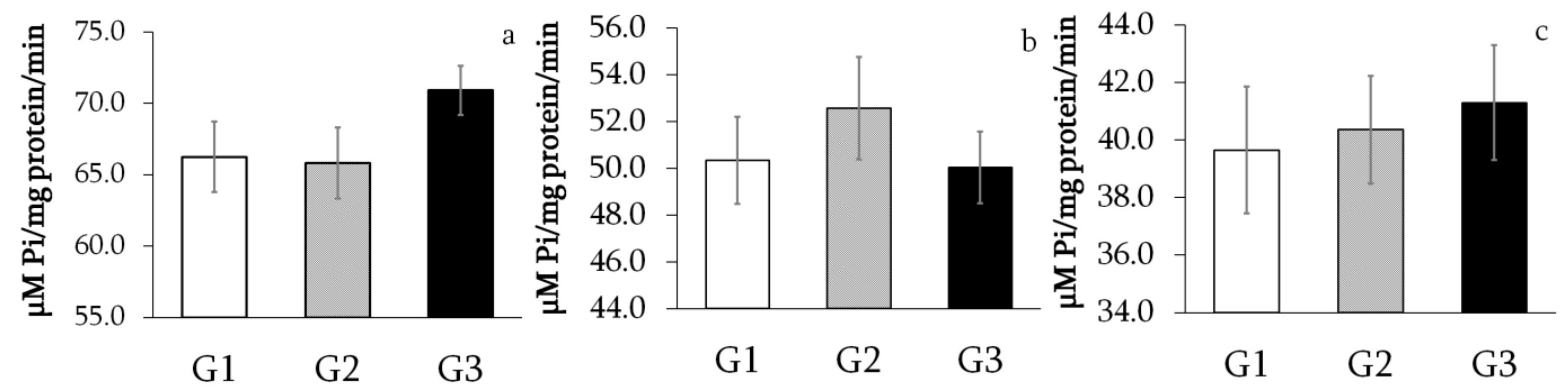

Figure 3. Alteration in plasma membrane (a), microsomal (b) and mitochondrial (c) $\mathrm{Ca}^{2+}$-ATPase activity in Non-aggressive (G1), Cr-treated non-aggressive (G2) and Aggressive (G3) animals. Data are mean \pm SEM for $n=8$ in each group 


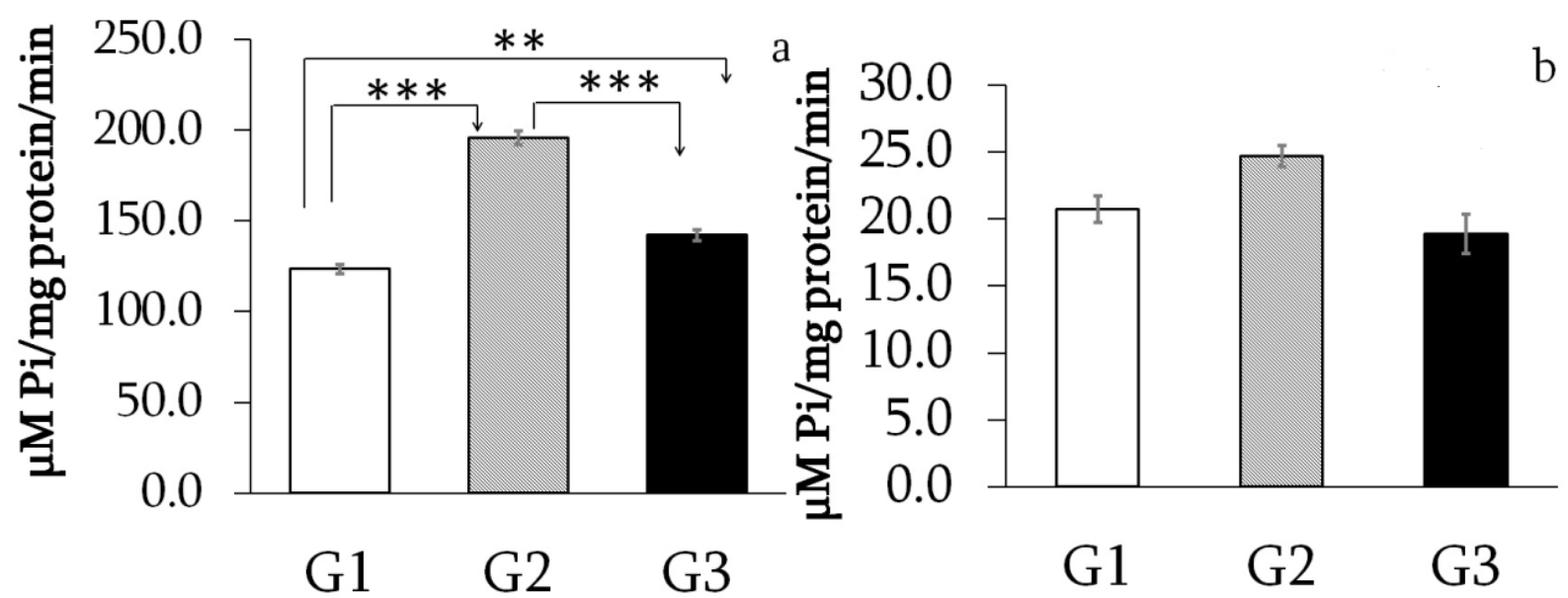

Figure 4. Alteration in hippocampal $\mathrm{Na}^{+} / \mathrm{K}^{+}$-ATPase (a) and $\mathrm{Mg}^{2+}$-ATPase (b) activity in Non-aggressive (G1), Cr-treated non-aggressive (G2) and Aggressive (G3) animals. Data are mean \pm SEM for $n=8$ in each group. $* * \mathrm{p}<0.01, * * * \mathrm{p}<0.001$

\section{Discussion}

The experimental observations show a significant difference in behavioral parameters of non-aggressive (G1) and naturally aggressive (G3) laboratory rats (Fig. 1). G3 animals exhibited a higher rate of exploratory activity and lower fear-related reactions, which is generally characteristic of aggressive behavior [19]. We also observed G2 and found that an extended, 30-day i.p. supplementation of $140 \mathrm{mg} / \mathrm{kg}$ $\mathrm{Cr}$ modified their behavioral parameters, which approximated those prevalent among G3. Similar effect was reported when depressed animals were fed $\mathrm{Cr}$ [6]. This makes it possible to suggest that therapeutically $\mathrm{Cr}$ may be potentially used as an anti-depressant solution [25]. Thus, results of our experiments are clearly compliant with the historical data that describe improvement of physiological characteristics among laboratory animals subjected to $\mathrm{Cr}$ diet, notwithstanding the difference in the forms of supplementation.

Aggressive and non-aggressive rats also differ by some biochemical parameters, such nitric oxide (NO) among others. It is an important mediator closely involved in various metabolic processes within the cell. Recent publications prove the importance of variation in $\mathrm{NO}$ concentration in the way various biochemical processes in the brain are regulated. Aggressive animals are known to be characterized by NO deficiency resulting from a lowered activity of its synthesizing enzyme - neuronal NO-synthase (Nanos) [26]. Therefore, injection of a selective Nanos inhibitor, such as 3-bromo-7-nitroindazole ( $3 \mathrm{BrN})$ into the rats increases the level of aggression [27]. Similar results were found in male rats with knockout nNOS gene [28]. It is worth noting that in our findings $\mathrm{NO}$ content in the hippocampus of G2 rats was significantly lower than that among G1 animals (Fig.2a). Values from G2 and G3 were identical, which serves as another argument in favor of $\mathrm{Cr}$ being a factor in development of aggression-related changes.

Under natural conditions, cellular NO is synthesized by NO-synthase (NOS) that is activated by $\mathrm{Ca}^{2+}$ and is, thus, sensitive to the concentration of the ion [29]. So, as the next step, content of the $\mathrm{Ca}^{2+}$ was determined in hippocampal samples among the animals of all the three groups. The findings indicated that $\mathrm{G} 3$ individuals did not display a significant change in the $\mathrm{Ca}^{2+}$ concentration compared to $\mathrm{G} 1$ animals (Fig. 2b). Such results differ from the data reported by other authors in that the latter speak of an intensified locomotor activity under a higher $\mathrm{Ca}^{2+}$ concentration as a sign of higher aggression level. The disparity may be accounted for by the difference in the experimental conditions applied by our team and the other authors. In particular, we studied the intracellular content of $\mathrm{Ca}^{2+}$ in the hippocampus of G3 rats. Godinho et al. [30], on the other hand, considered correlation of behavioral parameters when the individuals were injected calcium exogenously, which, in turn, increased the ion content in brain cells. Therefore, under constant calcium quantity, $\mathrm{NO}$ reduction in aggressive animals might be caused not by the $\mathrm{Ca}^{2+}$-dependent regulation of NO-synthase, but rather, as hypothesized by some authors, by a lower translation rate for mRNA [31]. However, another reason may lie in a reduced antioxidant activity and activated oxidative processes, which is characteristic of aggressive animals. This could be another impact on the activity of various enzymes, including the NO-synthase [32, 33].

Meanwhile, the results were different in case of G2 animals. In particular, extensive intake of $\mathrm{Cr}$ by non-aggressive animals reduced the $\mathrm{Ca}^{2+}$ content in hippocampal cells, compared to both G1 and G3 (Fig. 2b). In addition, PMCA and mitochondrial $\mathrm{Ca}^{2+}$-ATPase, as well as microsomal $\mathrm{Ca}^{2+}$-ATPase did not reveal any meaningful changes in their activities (Fig. 3). Based on our and recent scientific data, it could be hypothesized that reduction in the level of $\mathrm{Ca}^{2+}$ accompanied by i.p. supplementation of exogenous Cr may be due to Cr's modulating effect on the glutamate reuptake by the pre-synaptic membrane, which allows NMDA-receptors of the post-synaptic membrane to restrict $\mathrm{Ca}^{2+}$ influx into the cell and reduce its intracellular content $[34,35]$. 
As the functional and structural correlation between the NMDA-receptor and $\mathrm{Na}^{+} / \mathrm{K}^{+}$-ATPase is well known [36], we also studied the $\mathrm{Na}^{+} / \mathrm{K}^{+}$-ATPase activity across the three groups, namely in the hippocampal slices of the animals and established that aggressive individuals, as shown on figure $4 \mathrm{a}$, did exhibit higher $\mathrm{Na}^{+} / \mathrm{K}^{+}$-ATPase activity than non-aggressive rats, which is in accordance with scientific data $[37,38]$. The results were the same for $\mathrm{G} 2$ animals.

Scientific data suggest that the cause of the observed changes has to be not just $\mathrm{Cr}$ impact on glutamate reuptake, but also its direct influence on NMDA-receptor and modulation of NMDA-calcineurine signaling pathway, which increases $\mathrm{Na}^{+} / \mathrm{K}^{+}$-ATPase activity $[24,39]$. Involvement of the NMDA-receptor in the $\mathrm{Na}^{+} / \mathrm{K}^{+}$-ATPase and the correlation to $\mathrm{Cr}$ was also proved by a study that targeted the influence of $\mathrm{Cr}$ on $\mathrm{Mg}^{2+}$-ATPase activity (Fig. $4 b$ ). Unlike $\mathrm{Na}^{+} / \mathrm{K}^{+}$-ATPase, $\mathrm{Mg}^{2+}$-ATPase is known not to be regulated by the NMDA-receptor [40]. Our findings indicate that hippocampal cells of G1 and G3 rats do not display any significant changes in $\mathrm{Mg}^{2+}$-ATPase, unlike $\mathrm{Na}^{+} / \mathrm{K}^{+}$-ATPase. Thus, i.p. supplementation of $\mathrm{Cr}$ in $\mathrm{G} 3$ does not affect its activity.

Therefore, it would be reasonable to assume that extended $\mathrm{Cr}$ supplementation alters various physiological and biochemical characteristics among laboratory animals and also increases aggressiveness in non-aggressive individuals, due to its active role in energy metabolism, as well as its neuro-modulating action. However, the results are still insufficient to make definitive conclusions. We anticipate that further research in Cr's influence on NMDA-receptor and oxidative processes as part of aggression-linked changes will lead to a bigger and clearer picture in understanding molecular mechanisms of aggression and finding possible ways leading to its prevention.

\section{Conclusions}

To sum up, it is clear that extended $\mathrm{Cr}$ supplementation induces certain types of aggressive behavior in naturally non-aggressive individuals. In addition, it also changes biochemical parameters, by e.g. causing a decrease in NO and $\mathrm{Ca}^{2+}$ levels and in $\mathrm{Na}^{+} / \mathrm{K}^{+}$-ATPase activity.

Supposedly, such changes could be induced by the modulating effect of $\mathrm{Cr}$ on glutamate reuptake and alterations in NMDA receptor activity. Finally, it has to be pointed out that the results do not allow for any definitive conclusions and there is need for further and more detailed investigations.

\section{Acknowledgments}

This work was supported by the financial support of the Shota Rustaveli National Science Foundation of Georgia [grant number FR/226/7-220/13]. Any idea contained in this publication is the property of the authors and may not represent the opinion of the Shota Rustaveli National Science Foundation of Georgia.

\section{REFERENCES}

[1] Wallimann T., Dolder M., Schlattner U., Eder M., Hornemann T., O'Gorman E., Ruck A. and Brdiczka D. Some new aspects of creatine kinase (CK): compartmentation, structure, function and regulation for cellular and mitochondrial bioenergetics and physiology. Biofactors 8, 229-234; 1998

[2] Wyss M., Kaddurah-Daouk R. Creatine and creatinine metabolism. Physiol. Rev. 80, 1107-1213; 2000

[3] Bothwell J. H., Rae C., Dixon R. M., Styles P. and Bhakoo K. $\mathrm{K}$. Hypo-osmotic swelling-activated release of organic osmolytes in brain slices: implications for brain oedema in vivo. J. Neurochem. 77, 1632-1640; 2001

[4] Galbraith R. A., Furukawa M. and Li M. Possible role of $\mathrm{Cr}$ concentrations in the brain in regulating appetite and weight. Brain Res. 1101, 85-91; 2006

[5] Almeida L. S., Rosenberg E. H., Verhoeven N. M., Jakobs C. and Salomons G. S. Are cerebral creatine deficiency syndromes on the radar screen? Fut. Neurol. 1, 637-649; 2006

[6] Beard E., Braissant O. Synthesis and transport of $\mathrm{Cr}$ in the CNS: importance for cerebral functions. J. Neurochem. 115, 297-313; 2010

[7] Cagnon L. and Braissant O. Hyperammonemia-induced toxicity for the developing central nervous system. Brain Res. Rev. 56, 183-197; 2007

[8] Donnan G. A., Fisher M., Macleod M. and Davis S. M. // Lancet. Stroke. 371, 1612-1623; 2008

[9] Beal M. F. Energetics in the pathogenesis of neurodegenerative diseases. Trends Neurosci. 23, 298-304; 2000

[10] Chaturvedi R. K. and Beal M. F. Mitochondrial approaches for neuroprotection. Ann. N Y Acad. Sci. 1147, 395-412; 2008

[11] Caspi,A., Sugden, K., Moffitt, T.E., Taylor,A., Craig, I.W., Harrington, H., McClay, J., Mill, J., Martin, J., Braithwaite, A., Poulton, R., Influence of life stress on depression: moderation by a polymorphism in the 5 -HTT gene. Science 301, 386-389; 2003

[12] Duman, R.S., Monteggia, L.M., A neurotrophic model for stress-related mood disorders. Biol. Psychiatry 59, 1116-1127; 2006

[13] Pittenger, C., Duman, R.S., Stress, depression, and neuroplasticity: a convergence of mechanisms. Neuropsychopharmacology 33, 88-109; 2008

[14] Allen PJ. Creatine metabolism and psychiatric disorders: Does creatine supplementation have therapeutic value. Neuroscience and Biobehavioral Reviews 36, 1442-1462; 2012 
[15] Tachikawa M., Fukaya M., Terasaki T., Ohtsuki S. and Watanabe M. Distinct cellular expressions of creatine synthetic enzyme GAMT and creatine kinases uCK-Mi and CK-B suggest a novel neuron-glial relationship for brain energy homeostasis. Eur. J.Neurosci. 20, 144-160; 2004

[16] Rae C., Digney AL., McEwan SR., Bates TC. Oral Cr monohydrate supplementation improves brain performance: a double-blind, placebo-controlled, cross-over trial. Proc Biol Sci. 2; 270(1529):2147-50; 2003

[17] McMorris T., Harris R.C., Howard A.N. , Langridge G. , Hall B., Corbett J., Dicks M., Hodgson C. Creatine supplementation, sleep deprivation, cortisol, melatonin and behavior. Physiology \& Behavior 90 21-28; 2007

[18] Burjanadze GM, Kuchukashvili ZT, Chachua MV, Menabde KO, Dachanidze NT, Koshoridze NI. Changes in activity of hippocampus creatine kinase under circadian rhythm disorders. Biological Rhythm Research. 2014.45, 5 685-697, 2014

[19] Takahashi A, Quadros IM, de Almeida RM, Miczek KA. Behavioral and pharmacogenetics of aggressive behavior. Curr Top Behav Neurosci. 12:73-138; 2012

[20] Brittney M. Cox, Mrudang M. Shah, Teri Cichon, Manuel E. Tancer, Matthew P. Galloway, David M. Thomas and Shane A. Perrine Behavioral and neurochemical effects of repeated MDMA administration during late adolescence in the rat Prog Neuropsychopharmacol Biol Psychiatry.; 48: 229-235; 2014

[21] Deminice R, Rosa FT, Franco GS, Jordao AA, de Freitas EC. Effects of creatine supplementation on oxidative stress and inflammatory markers after repeated-sprint exercise in humans. Nutrition 29: 1127-1132. 2013

[22] Stefani GP, Nunes RB, Dornelles AZ, Alves JP, Piva MO, Domenico MD, Rhoden CR, Lago PD. Effects of creatine supplementation associated with resistance training on oxidative stress in different tissues of rats. J Int Soc Sports Nutr. 11:11-18. 2014.

[23] Rambo LM, Ribeiro LR, Schramm VG, Berch AM, Stamm DN, Della-Pace ID, Silva LF, Furian AF, Oliveira MS, Fighera MR, Royes LF. Creatine increases hippocampal $\mathrm{Na}+/ \mathrm{K}+-\mathrm{ATPase}$ activity via NMDA-calcineurin pathway. Brain Res Bull. 88:553-559; 2012

[24] Miranda K. M., Espey M. G., Wink D. A. A Rapid, Simple Spectrophotometric Method for Simultaneous Detection of Nitrate and Nitrite. Nitric Oxide. 5, 1, pp. 62-71; 2001

[25] Allen PJ, D'Anci KE, Kanarek RB, Renshaw PF, Chronic creatine supplementation alters depression-like behavior in rodents in a sex-dependent manner. Neuropsychopharmacolo gy $35: 534-546 ; 2010$

[26] Chiavegatto S., Nelson RJ. Interaction of nitric oxide and serotonin in aggressive behavior. Hormones and Behavior 44 233-24, 2003

[27] Trainor BC. Workman J L, Jessen R., Nelson R J. Impaired Nitric Oxide Synthase Signaling Dissociates Social
Investigation and Aggression. Behav Neurosci. 121(2): 362-369, 2007

[28] Nelson RJ, Chiavegatto S. Molecular basis of aggression. Trends in Neurosciences 24:713-719, 2001

[29] Miller U., Bicker G. Calcium-activated Release of Nitric Oxide and Cellular Distribution of Nitric Oxide-Synthesizing Neurons in the Nervous System of the Locust. The Journal of Neuroscience, 74(12): 7521-7528; 1994

[30] Godinho A.F., Trombini T.V., Oliveira E.C. Effects of elevated calcium on motor and exploratory activities of rats. Braz J Med Biol Res, 35(4) 451-457, 2002

[31] Nathan C., Xie Q. Nitric oxide synthases: roles, tolls and controls. Cell, 78, 915-918, 1994.

[32] Demas G. E., Eliasson M. J., Dawson T.M. Inhibition of neuronal nitric oxide synthase increases aggressive behavior in mice. Mol. Med. 3, 9, 610-616, 1997

[33] Ferrari P.F., Palanza P., Parmigiani S., de Almeida R.M.M., Miczek Klaus A. Serotonin and aggressive behavior in rodents and nonhuman primates: Predispositions and plasticity. European Journal of Pharmacology 526, 259-273, 2005

[34] Magni, D.V., Oliveira, M.S., Furian, A.F., Fiorenza, N.G., Fighera, M.R., Ferreira, J., et al., Creatine decreases convulsions and neurochemical alterations induced by glutaric acid in rats. Brain Research 1185, 336-345, 2007

[35] Genius J, Geiger J, Bender A, Möller HJ, Klopstock T, Rujescu D. Creatine protects against excitoxicity in an in vitro model of neurodegeneration. PLoS One. ; 7(2):e30554, 2012

[36] Carvalho F B, Mello Carlos F, Marisco Patricia C. , Tonello Raquel , Girardi Bruna A. , Ferreira J, Oliveira MS., Rubin M A. Spermidine decreases $\mathrm{Na}+, \mathrm{K}+$-ATPase activity through NMDA receptor and protein kinase $G$ activation in the hippocampus of rats. European Journal of Pharmacology 684, 79-86, 2012

[37] Aksenov M, Aksenova M, Butterfield D A. and Markesbery WR. Oxidative Modification of CK-BB in Alzheimer's disease Brain. J. Neurochem., Vol. 74, No. 6, 2520-2527; 2000

[38] Gonçalves J F., Nicoloso FT, da Costa P, Farias JG, Carvalho FB, da Rosa MM, Gutierres JM, Abdalla FH et al., Behavior and brain enzymatic changes after long-term intoxication with cadmium salt or contaminated potatoes. Food and Chemical Toxicology 50, 3709-3718; 2012

[39] Royes, L.F., Fighera, M.R., Furian, A.F., Oliveira, M.S., Fiorenza, N.G., Ferreira, J. Neuromodulatory effect of creatine on extracellular action potentials in rat hippocampus: role of NMDA receptors. Neurochemistry International 53, 33-37; 2008.

[40] Turner CE, Byblow WD, Gant N. Creatine supplementation enhances corticomotor excitability and cognitive performance during oxygen deprivation. J Neurosci 35:1773-1780; 2015 